\title{
Formation of Tourist Image of the Region
}

\author{
Anna A. Larionova \\ Moscow State University of Design and Technology, Russian Federation \\ Irina A. Suslova \\ Elena V. Povorina \\ Russian State University of Tourism and Service, Russian Federation \\ Marina V. Vinogradova \\ Russian State Social University, Russian Federation \\ Email: annla@list.ru
}

\section{Doi:10.5901/mjss.2015.v6n3s5p261}

\section{Abstract}

The purpose of the study of tourist image of the region as a basis for the development of domestic tourism was a compilation of existing research approaches and results of original research in this field. In particular, the main scientific and practical interpretations of the definition of the image are studied, and the authors' interpretation of the phenomenon is given. The article also describes the principles of the use of a special approach, built upon the use of marketing techniques that highlight the region among others: in some cases, the basis of regional image formation is defined by unique objects, representing the world's value of cultural and historical heritage, while in others new objects of tourist attraction are being created. Article notes that the regional level approaches to the formation of the image of the region are being elaborated. Importance of the two components of the tourist image of the region are justified: informational and appraisal. Based on the research of methods and practices, as well as on the authors' developments, article suggests an approach to the formation of a tourist image of the region in an example of Pushkin municipal district of the Moscow region. The authors of the study have focused on disclosure of informational and the appraisal components of the tourist image of the region. Moreover, based on research results, it is justified that the proposed approaches to the formation of tourist image of the region will not only enable to identify and make a fuller use of the existing tourism potential, but will also contribute to the successful resolution of a number of important socioeconomic issues for future development. All authors' recommendations brought down to the concrete proposals and are directed to the successful promotion of Pushkin municipal district in the competitive market of the Moscow region and the implementation of its tourism potential.

Keywords: region, tourist image, domestic tourism, tourist attractiveness, tourist potential

\section{Introduction}

Under the current socio-economic circumstances, individual regions of the country are increasingly seen not as geographic territories, but as subjects competing in the market to attract the necessary resources for development. From the perspective of the tourism industry, regions act as special tourism products, requiring successful promotion. The level of attractiveness of the region in the tourist market is determined by the pace of tourism development on its territory, as well as the role and place in the state of the economy.

Modern negative changes in the world economy and politics have made significant adjustments to the development strategy being planned. For the first time in several years, the expenditures of Russian citizens on tourism reflect a sharp decline. Significantly decreased the international passenger traffic: in 2012, as many as 15,332,136 people have travelled abroad. In 2013, this figure was 18,291,737 pers., while in 2014 the number of tourists who travelled abroad was 17,611,569 pers. (Rosturizm, 2015). A difficult season for the tourism industry in 2014 has nevertheless brought some positive moments. For instance, the volume of domestic tourism in Russia increased by $38 \%$. It is these trends that make the regional authorities of the country to actively develop domestic tourism.

Numerous studies have shown, that the pace of tourism development in the region is largely determined by the 
state of its tourist image (Dzhandzhugazova, 2008; Voznyuk, 2009; Vazhenina, 2010; Dinny, 2013; Vinogradova, 2009; Zaitseva, 2013). Despite the fact that the topic of tourist image of being actively discussed throughout the world, including in Russia, many Russian regions lag behind the best practices. Thus, despite the huge amount of work done to restore the architectural and historic buildings and complexes, Moscow is still inferior in popularity among domestic and foreign tourists to St. Petersburg, while the tourist routes of 'Golden Ring of Russia' often attract the lovers of the historical past of Russia.

Most studies within the framework of the regional tourist image are dedicated to the formation image of the country and major cities. Major cultural centers of Russia, such as St. Petersburg, Vladivostok, Kaliningrad and others, have developed and adopted their own programs for the image development. Representatives of the regional authorities are increasingly coming to understand the importance of the problem of formation and development of tourist image of a certain territory. But the regional level approaches to the formation of the image of the region are only being formed, thus, an object of study was chosen the Pushkin municipal district of the Moscow region. The region does not possess any unique objects of tourist attraction.

\section{Literature Review}

Contemporary researchers engaged in the scientific field consider the image formation from different perspectives: the psychological, informational, sociological, corporate, marketing, regional and others. Wherein, the concept of 'image' can be attributed to any entity: the individual, product, company, city, region, country. However, in any theoretical and methodological approach scholars are trying to clarify the concept of "image", as to identify the principles and mechanisms of its formation for the effective inclusion in the socio-economic reality and goal achievement (Table 1).

Table 1. Interpretation of the basic scientific approaches to defining the notion of image

\begin{tabular}{|c|c|}
\hline Scientific approach & Interpretation \\
\hline \multirow[t]{2}{*}{ Psychological } & Set of beliefs and feelings generated by the audience (Dowling, 2003) \\
\hline & An idea of someone's internal guise, image (Ozhogov \& Shvedova, 2003) \\
\hline \multirow[t]{2}{*}{ Informational } & Result of the interaction of internal and external communications of the company (Shkardun and Yahtyamov, 2001) \\
\hline & Representation, formed by the media, including advertising (Vechkanov, 2002) \\
\hline Sociological & $\begin{array}{l}\text { Reputation, goodwill, product quality, the accuracy of implementation of commitments, forms of communication with } \\
\text { customers (Borisov, 2004) }\end{array}$ \\
\hline \multirow[t]{3}{*}{ Corporate } & Reputation, public perception of the company, firm, formed by customers, suppliers, consumers, etc. (Zaitsev, 2006) \\
\hline & $\begin{array}{l}\text { Image, reputation, opinion of customers and consumers about the prestige the company, its products and services (Ji, } \\
\text { 2000) }\end{array}$ \\
\hline & Perception of the company or its products by society (Kotler, 1990) \\
\hline \multirow[t]{2}{*}{ Marketing } & Product images, product reputation, brand image, enterprise and the country of origin (Stavrukov, 1999) \\
\hline & The image of the product, service, enterprise, set of related associations and impressions about them (Azriliyan, 2006) \\
\hline \multirow[t]{4}{*}{ Regional } & $\begin{array}{l}\text { Complex of individual associative representations, which forms the basis of a basic understanding that correlate with } \\
\text { individual region (Dzhandzhugazova, 2008) }\end{array}$ \\
\hline & $\begin{array}{l}\text { A set of sensations and visual images of people on the natural and climatic, historical, socio-economic, political, moral, } \\
\text { psychological and other features of the area (Vazhenina, 2010) }\end{array}$ \\
\hline & The sum of beliefs, attitudes and experiences of people (Asplund et al., 2005) \\
\hline & $\begin{array}{l}\text { A set of emotional and rational individual representations about the region, as well as personal experience and rumors } \\
\text { affecting the creation of a specific image (World Tourism Organization - UNWTO) }\end{array}$ \\
\hline \multirow[t]{7}{*}{ Complex } & 1. Face of the company in the mirror of public opinion; \\
\hline & Image, helping to consolidate the consumer's perception of the product; \\
\hline & Reputation of the company, which forms the general opinion about the qualities, pros and cons; \\
\hline & Company image in the eyes of customers, partners, investors, state (Godin, 2006) \\
\hline & Image that helps to consolidate consumer's habits and perceptions of the product; \\
\hline & \\
\hline & $\begin{array}{l}\text { Company's goodwill that is formed by the general public over the qualities, advantages and disadvantages } \\
\text { (Ephremova, 2000) }\end{array}$ \\
\hline
\end{tabular}

Haven made the compilation of the definitions we can conclude that image always reflects the opinion of general public, emerging from the set of images, ideas, interpretations and assessments. Positive image contributes to realization of the planned tasks. As noted in the study of Crouch and colleagues (Crouch et al., 2015), attribute plays an important role in shaping decisions on a leisure trip. At the same time, we believe a tourist image of the region should be understood not 
just as successfully advanced positive image of the territory, which is based on the distinctive capabilities able to meet the needs of specific customer segments, but also as a more inclusive term that includes:

- original, emotional and attractive public perception of natural, historical, cultural, social, ethnic, scientific, industrial, environmental characteristics of the region;

- provision of qualitative characteristics of the services provided being in demand of the target groups of consumers

- achieved public the level of tourist attractiveness of the region and the tendency of its increase, formed by a special set of positive associations, symbols, signs, techniques.

\section{Research Methodology}

Up-to-date a rich scientific and practical material for the study and application of various techniques and technologies of image formation has been accumulated. Yet most empirical studies in the framework of regional image formation are often limited to the development of regional symbols and the creation of special Internet sites of the region. In more rare cases, these actives are being supplemented by the organization of exhibitions and cultural events. Application of public relations, marketing, advertising, as well as promotion on the Internet techniques for the formation on an image of the area are described in the works of Asplund et al., 2005; Rice and Trout, 2004; Beerli and Martın, 2004; Pan and Xiang, 2011.

However, the formation of tourist image of the region involves the use of a special approach, built on the use of marketing techniques of highlighting a specific region among others. This methodological approach includes the following steps (see Suslova, 2012): diagnostic of the features and characteristics of the region, the formation of the institutional framework for the construction of the image, the creation of informational products that reflect a positive image of the region, the market commercialization of the tourism products, and evaluation of results. This article is based on this aspect while identifying the specific features of the area.

Basis for the formation of tourist image of the region is its distinction from other areas, providing increased interest from tourists, investors, and authorities. Thus in some cases, the basis of image formation is defined by unique objects that represent the world's cultural and historical heritage, their new interpretation (Zerva, 2015). The world experience shows (Anholt, 2010), that the culture in the form of various projects and development scenarios can lead depressed areas of the city to a new level of development. A well-known example of the Spanish city of Barcelona, which in just twenty years has transformed from a dirty, smoky industrial center into a clean, open cultural city of global significance (Dinny, 2013), as well as the cities of the 'Golden Ring of Russia' tourist route. In other cases, a rather original approach to the creation of new objects of tourist attractions was applied, such as Museum of the mouse in Myshkin city of the Yaroslavl region of Russia. Quintessence of image formation is 'compression' or 'processing' a significant amount of information about the area.

The tourist image of the region cannot be the same for all groups of potential customers. Based on the goals, objectives and characteristics of the region being set, it enhances the audience of the target segments. It seems that the construction of the tourist image of the region, especially its ability to reflect the attractiveness not only for tourists but also for all interested agencies, organizations, the existing or potential investors should be based on the disclosure and successful use of its tourist potential, as being noted by Suslova (2013). It is generally recognized that the basis of the regional tourism potential are:

- the objects of tourism, which define the content of tourist interest in the administrative territory;

- the elements of infrastructure of the tourism industry, administrative territory, including the organizations engaged in tourism activities, transportation, catering, accommodation, communications, insurance, fitness and recreation, souvenirs' production, products of folk arts and crafts, trade and other services.

This is confirmed by the results of the study held by Hacia (2014), who suggests that the formation of tourism development also depends on the creation and implementation of a policy of close relationship between transport and tourism aspects of urban logistics and others. The composition and characteristics of the tourist facilities located in the region determine the possibility of development of certain kinds of tourism in its territory: historical and cultural, pilgrimage, sports, health, military, patriotic, educational, agricultural, and other (e.g. see Marcelo, 2009). The scope and structure of the elements of the tourism industry in the region form its material and technical base, which defines the essence of ongoing tourist activity, as it provides necessary conditions for the delivery of a full range of services (transportation, catering, accommodation, excursions, etc.). The material - technical base of tourism in the region in its composition, capacity, quality and quantity of elements must satisfy the needs of tourists (Povorina, 2010). Otherwise, it 
is impossible to provide the required level of service quality and to achieve the desired performance of the proposed tourism product (Suslova, 2012). A study of Lin and Huang (2009) presents a model for estimating the position of the image by tourists.

Thus, based on a number of previous studies and approaches to the formation of the image of the region, this article offers two main components of regional tourism potential: a) descriptive or informational, which characterizes the tourist image of the region, the totality of all knowledge and understanding of it; b) appraisal (i.e. evaluation), which is related to the prevailing social attitudes towards the tourist image of the region. The appraisal component exists due to the fact that the information stored in the memory is not indifferent to the individual's perception. It causes certain estimates and emotions that have different intensities based on their positive perception of indifference or strong condemnation.

\section{Tourist Image of the Pushkin Municipal District of the Moscow Region}

Based on the research methodology and best practices, as well as personal theoretical developments of the authors, we shall attempt to apply the proposed approach to the formation of regional tourist image to the Pushkin municipal district the Moscow region. In this respect, it is advisable to proceed with the specific geographical location and tourist resources available. Pushkin district is located in the Northeast of Moscow region, $30 \mathrm{~km}$ from Moscow, and enters an area of Moscow suburbs. It is located between the two cultural centers of Russia - the Moscow capital city and Sergeyev Posad, which has an architectural monument of culture and art, featured in the World Heritage List of UNESCO - the TrinitySergius Lavra. The area of the district is 630 square $\mathrm{km}$, of which about $45 \%$ is woodland.

Studies conducted by the authors in the Russian State University of Tourism and Service showed that the basis of tourism resources of the area are:

1. Natural resources: deciduous and coniferous forests, fields, meadows, 10 lakes, shores of the Pestovo reservoir, 20 rivers, including the river Klyazma, with the total length of $205 \mathrm{~km}$ on the territory of the district.

2. Recreational resources: natural wellness (forests, fields, ponds), therapeutic institutions (resorts, recreation complexes of different profiles), sports and recreation facilities (sports palaces, sports complexes, sports bases, stadiums).

3. Cultural and historical resources: Orthodox religious sites (more than 20 churches, including four of the $17^{\text {th }}$ century, two of the $18^{\text {th }}$ century, eight of the $19^{\text {th }}$ century, ten chapels); country estates, including 4 projects of federal significance: 'Muranovo', 'Lyubimovka', 'Mamontovka', and 'Mogiltsy'; museums (over 10); historical monuments, including the first industrial enterprises and railway stations of the central Russia founded in the late $19^{\text {th }}$ century; cultural monuments associated with the life and the rest of famous writers, poets, artists, actors, scientists of the country.

4. Event-related resources:

- activities of culture and art (Musical Festival, a festival of choral music 'Pushkin's Wreath', poetry contests, art exhibition 'Lilac Festival', exhibition of the 'Pushkin Art Gallery', summer dance evenings, etc.);

- holidays (e.g. 'Day of the city Pushkin', 'Wide carnival', 'Youth Day', 'Tourism Day', etc.);

- sporting events (e.g. interregional canoeing competition, dog sledding competitions, etc.).

Thus, a feature of Pushkin district is the presence of a large number of different types of natural resources that provide opportunities for recreation, rehabilitation, treatment, cultural and historical knowledge, entertainment, etc. On this basis, we shall build a tourist image of the region. It is possible to position the Pushkin municipal district as a natural gem of the Moscow suburbs, where Russian tourists in close proximity to Moscow (the largest megalopolis in the country and the world) can:

- see a variety of natural sites and attractions of the central Russia (the Russian plain);

- make use of various types of complex recreational services offered by medical resorts and recreational and sports organizations;

- visit the colorful celebrations, festivals and sporting events held in the natural objects of the area;

- better understand the beauty of Orthodox churches and chapels located in the district, which location and architecture is always in harmony with nature;

- assess the architecture of country estates that take into account the specifics of their natural placement;

- understand why for centuries known famous representatives of the Russian and Soviet society have tied their lives, leisure and work with this region.

Thus, we shall disclose the narrative or informational content of the tourist image of the area. Taking into account 
the appraisal component in the formation of tourist image of the region we shall focus on the following issues:

1. The condition and degree of preservation of tourist facilities.

2. The state of the settlements in the region.

3. Transport accessibility of the objects of tourist attraction.

4. The number and condition of accommodation and catering facilities.

5. Availability of communications.

6. Environmental conditions and safety of travel.

7. The souvenir and retail services, other consumer services.

A material and technical base required to provide the necessary level of services cannot be achieved without an integrated approach to solving the existing problems in the region. Thus, a successful promotion of Pushkin area in the competitive market of the Moscow region and the following implementation of its tourism potential would be impossible.

The process of formation of the image of the district on the tourist market is advisable to carry out in stages with the consolidation and expansion as the material - technical base, and its tourist potential in general. We suggest the following stages of its formation:

First stage. Development and promotion of bus and walking tour programs of various thematic focus, revealing features of tourist attractions of the area (for example, 'Natural Attractions of the Pushkin District', 'Rivers of Pushkin city and Pushkin area', 'Flora and fauna of the Russian Plain', 'Temples of Pushkin', 'Ancient country estates of Pushkin area', 'Pushkin dacha').

Second stage. Partial integration of the prepared excursion programs into famous and popular among the Russian tourists routes covering the area of the district: a) daily trips to the holy orthodox places, the Sergiev Posad and Radonezh; b) multi-day trips to the 'Golden Ring of Russia' in Pereslavl-Zalessky, Rostov Veliky, Yaroslavl; c) one or more days trips to the cities of the Moscow region.

Third stage. Independent tour operator activity for the development of tourist programs designed for one-day and multi-day stay of tourists in the district, based on the use of existing and further created objects of tourist interest, as well as modernized and updated material - technical base of tourism infrastructure. The main possible tour activities with respect to the proposed tourist image of the area can become different kinds of environmental, health, medical, sports, holiday, family, countryside, religious, historical and cultural tourism.

Currently, the tourism business is the area represents more than 20 firms. The total volume of their services in 2009 amounted to $104.5 \mathrm{mln}$.rub. In 2010 the total amount was $114.9 \mathrm{mln} . r u b$, in 2013 - $138.8 \mathrm{mln}$. rub. However, the basis of their activity is outbound tourism. Only one travel agency organizes and conducts tours of the historical and pilgrimage sites located on the territory of Pushkin district.

The proposed approaches to the formation of tourist image of the region will not only lead to the identification and fuller use of its existing economic potential, but will also contribute to the successful solution of a number of important socio-economic issues of the future development, including: development of domestic tourism; promotion of new types of tourism; improving the balance of the market of tourist services; formation of a package offer for tour operator activities; implementation of an active promotional activities; emergence of the economic feasibility of modernization of tourism infrastructure; attraction of additional investment in the development of tourism infrastructure; development of small enterprises; creation of new jobs; increasing the employment rate of the working population; increase in revenues to the budgets of all levels; improving the quality of life of local people.

\section{Conclusion}

It seems that for the development of domestic tourism in Russia, special attention should be paid to the formation of tourist image of individual regions. Local authorities and structure of the tourism industry should act as subjects of the given process, while the objects are the target customers: tourists and potential investors. The practical significance of this study is that research results are formulated into the specific recommendations and proposals for the management of image formation in the region and can also be used by other regions. The study provides valuable information for designers in the field of tourism and marketing professionals attempting to develop offers that are tailored to the needs of their target markets. At the same time, it should be understood that the process of image formation is very dynamic and it is necessary to conduct further research in the field of regional image formation. 


\section{References}

Anholt, S. (2010). Places: Image, Identity and Reputation. Palgrave Macmillan.

Asplund, K., Kotler F., \& Rein, I. (2005). Marketing of Places. Attraction of investments, businesses, residents and tourists to the cities, communes, regions and countries of Europe. St. Petersburg: Peter.

Azriliyan, A.N. (2006). New Dictionary of Economics. Moscow: Institute of New Ecomony.

Beerli, A., \& Martín, J. (2004). Tourists' characteristics and the perceived image of tourist destinations: a quantitative analysis - A Case Study of Lanzarote, Spain. Tourism Management, 25 (5), 623-636.

Borisov, A. B. (2004). Great Dictionary of Economics. Moscow: Book World.

Crouch, G. I., Oppewal, H., \& Huybers., T. (2015). Tourist Destination and Experience Choice: A choice experimental analysis of decision sequence effects. Tourism Management, 48, 467-476.

Dinny, K. (2013). Branding Territories. Best Global Practices. Moscow: Mann, Ivanov and Ferber. [in Russian]

Dowling, G. (2003). Reputation of the Company: Creation, Management and Performance Evaluation. Moscow: INFRA-M.

Dzhandzhugazova, E. A. (2008). Marketing of Tourism Areas: Textbook. Moscow: Publishing Center «Academy».

Ephremova, T. F. (2000). New Dictionary of the Russian Language. Explanatory - derivational. (In 2 Vol.) Vol. 1. Moscow: Rus. Yaz.

Godin, A. M. (2006). Branding: The Tutorial. Moscow: Dashkov and K.

Hacia, E. (2014). The Development of Tourist Space in Polish Port Cities. Social and Behavioral Sciences, 151, 60-69.

Ji, B. (2000). The Company's Image. Planning, Organisation, Promotion. St. Petersburg: Peter.

Kotler, F. (1990). Principles of Marketing. Moscow: Progress.

Lin, C., \& Huang, Y. (2009). Mining tourist imagery to construct destination image position model. Expert Systems with Applications, 36 (2), 2513-2524.

Marcelo, R.-V. M. (2009). Rural-cultural Excursion Conceptualization: A local tourism marketing management model based on tourist destination image measurement. Tourism Management, 30(3), 419-428.

Olli, D. (2013). The Challenges for the European Tourism Sustainable. Mediterranean Journal of Social Sciences, 4(9), 464-468.

Ozhogov, S. I., \& Shvedova, N. U. (2003). Explanatory Dictionary of the Russian Language. Moscow: Azbukovik.

Pan, B., \& Xiang, Z. (2011). Travel queries on cities in the United States: Implications for search engine marketing for tourist destinations. Tourism Management, 32 (1), 88-97.

Povorina, E. V., \& Vapnyarskaya, O. I. (2010). Approaches to Ensuring the Accessibility of Services in the Region. Service in Russia and Abroad, 1 (16), 164-172.

Povorina, E. V. (2010). The Concept of the Availability of Services: Theoretical and practical aspects. Service in Russia and Abroad, 3 (18), 115-119.

Rice, E., \& Trout, D. (2004). Positioning. The Battle for Recognition. St. Petersburg: Peter.

Rosturizm. [Online] Available: http://www.russiatourism.ru/contents/statistika (March 3, 2015).

Shkardun, V. D., \& Yahtyamov, T. M. (2001). Estimation and Formation of the Corporate Image of the Company. Marketing in Russia and Abroad, 3, 14-18.

Stavrukov, N. T. (1999). Concise Dictionary - A Guide to Marketing. St. Petersburg: Politehnica.

Suslova, I. A. (2012). Approaches to the formation of tourist image of the region. Service in Russia and Abroad, 6 (33), $101-107$.

Suslova, I. A. (2013). The nature and problems of the formation of tourist image and the region. Service in Russia and Abroad, 6 (44), $58-63$.

Vazhenina, I. S. (2010) The Image and Reputation of the Area. Regional Economy: Theory and Practice, 23, 2-12.

Vechkanov, G. S., \&Vechkanova, G. R. (2002). Modern Economic's Encyclopedia. St. Petersburg: Lan.

Vinogradova, M. V. (2009). Complex of tourism as part of the regional economy. Service Plus, 3, 78-82.

Voznyuk, E. E. (2009). Positioning and Shaping of Tourist Image of the Region that does not have Unique Objects of Attraction. Proceedings of the 7th International Symposium on Imageology "Imageology 2009: The Innovative Technologies of Success Against Crisis", Moscow.

World Tourism Organization (UNWTO). [Online] Available: http://www2.unwto.org (February 25, 2015).

Zaitsev, N. L. (2006). Concise Dictionary of Economist. Moscow: INFRA-M.

Zaitseva, N.A. (2013). The forecast of development of the hotel business in Russia as a promising direction of business expansion of international hotel chains. Middle East Journal of Scientific Research, 14 (3), 328-334

Zerva, K. (2015). Visiting authenticity on Los Angeles Gang Tours: Tourists backstage. Tourism Management, 46, 514-527. 